\title{
NATIONAL SECURITY AND PUBLIC ADMINISTRATION
}

\section{Viktoriia Zagurska-Antoniuk}

\author{
Zhytomyr Polytechnic State University, Zhytomyr, Ukraine
}

\begin{abstract}
Summary. The paper deals with the problem of national security in the contemporary world which is greatly influenced by the process of globalization and digitalization. The role of national security in modern state construction is highlighted in this paper. The following issue has been of great interest to many outstanding scientists worldwide especially since the beginning of the XXI century. However, the subject matter of national security in the system of public administration has not been clearly defined yet. Therefore, the approaches to define national security are analyzed and its distinctive feature are pointed out. Moreover, it is emphasized that at the level of national, regional and global relations the concept of national security is often associated with security strategies. Thus, emphasis is put on the predominant characteristics that help to distinguish between these two concepts. In addition, the characteristic features of national security as well as state security are clarified in this investigation. Security, like many other categories of social sciences, does not have a conclusive definition. What is more, the category of security has an interdisciplinary significance. Therefore, scientists define it in accordance with the subject matter and the specifics of cognition and research. Nevertheless, many outstanding scholars view security as an anthropocentric category related to man's social essence and value. Most scientists agree that security is a constituent of every aspect of human life. Consequently, the consideration of security problems is of great significance. All in all, nowadays it is very important to achieve the state of security as our globalized society frequently leads to different challenges and dangers. The results of the research contribute to better understanding of the problem and make it possible to introduce effective mechanisms of public administration in the field of national security.
\end{abstract}

Key words: security, geopolitics, state security, public administration, national security, national interests, transformational changes.

\section{УДК 351:327.5}

\section{НАЦІОНАЛЬНА БЕЗПЕКА ТА ПУБЛІЧНЕ УПРАВЛІННЯ}

\author{
Вікторія Загурська-Антонюк
}

\section{Державний університет «Житомирська політехніка», Житомир, Украӥна}

\begin{abstract}
Резюме. Проблемою національної безпеки в сучасному світі та ї̈ ролі у формуванні сучасних держав зацікавилося багато вчених у різних наукових галузях, особливо від початку ХХІ століття. Проте не існує у дослідженнях однозначно та конкретно визначеного предмета національної безпеки у системі державного управління. В наукових дослідженнях, присвячних даній проблематиці, часто ототожнюються поняття національної безпеки та стратегії безпеки на рівні національних, регіональних $i$ глобальних відносин. Безпека як $і$ багато інших теоретичних категорій у суспільних науках, немає єдиного і чіткого визначення. Адже ия категорія має міждисииллінарне значення. Тому науковиі різних наукових галузей трактують його відповідно до їх предмета вивчення, специфіки пізнання та дослідження. Але, не зважаючи на це, більшість дослідників погоджуються з тим, що безпека $\epsilon$ категорією антропоцентричною - пов'язаною із суспільною сутністю та иінністю людини. Адже у кожній сфері та кожному аспекті людського життя можна розглядати проблематику безпеки. Сьогодні не існує стійких наукових стереотипів щуодо визначення феномена національної безпеки. Тому життєво необхідни, практично для всіх сучасних суспільств, є фундаментальне обтрунтування даного феномена в системі державного управління. Особливого значення цее набуває в умовах геополітичних та глобальних
\end{abstract}


трансформащій. Від ступеня адекватності такого обтрунтування залежить тривалість та ефективність трансформаційних прочесів, поступальний історичний розвиток суспільств за умов збереження національної самобутності. Проблемою національної безпеки в сучасному світі та їі ролі у формуванні сучасних держав зачікавилося багато вчених різних наукових галузей, особливо від початку XXI століття. Проте у дослідженнях не існує однозначно та конкретно визначеного предмета національної безпеки в системі державного управління. У наукових дослідженнях, присвячних даній проблематиці, часто ототожнюються поняття начіональної безпеки й стратегії безпеки на рівні національних, регіональних і глобальних відносин. Основною метою статті є здійснення аналізу щзодо визначення понять «національної безпеки» в системі «державного управління». Також слід визначити суспільно-політичне підпорядкування изих систем; суб' єктивацію національної безпеки та ї̈ регулювання в системі державного управління.

Ключові слова: безпека, геополітика, державна безпека, публічне управління, національна безпека, трансформачійні зміни.

Introduction. Global change in the process of transformation of pre-industrial societies into industrial ones, and then into high-tech and informatized ones, was accompanied by changes that both directly and indirectly threatened peoples, states and civilization security. Therefore, the characteristic feature of the modern world development is the intensification of transnational processes, in which global problems are becoming increasingly important.They affect humanity in general and each state (society) in particular, thus conglomerate the contradictions of social development. Dramatic geopolitical changes at the beginning of the 21 st century indicate that the world has entered a phase of another global transformation, which can result in crises and dangers to the world order.

Since early 1990s, the modern world has undergone the transition to polycentrism, the formation of which is accompanied by escalation of economic, geopolitical, ethno-confessional, demographic and other contradictions between the power centers and the world civilization. The $20^{\text {th }}$ century was one of the most tragic and dangerous epochs, as it was marked by the growing confrontation between two antagonistic socio-political systems. However, selfliquidation of one of the components of the bipolar world order did not lead to general peace. On the contrary, having lost the balance due to bipolarity disintegration, civilization has faced the growing conflict caused by contradictions inthe world's leading states national interests as well as emergence of a new threats system to their security. Currently a fundamentally new scientific approach is needed in order to understand the situations in-depth. It is especially significant for transitional societies that are reviving their statehood, which is associated with the need of ensuring the reliable national security [10, p. 53].

Nowadays there are no conclusive scientific approaches to the definition of «national security» concept. Consequently, a thorough interpretation of the concept in the system of public administrationis is very important for almost all modern societies. It is especially important at the time of geopolitical and global transformations. The adequacy of this interpretation has a great influence on the duration and efficiency of transformation processes, as well as progressive historical development of the societies providing national identity preservation [5, p. 233].

The beginning of the XXI century is marked with considerable scientific interest in the problem of national security in the modern world and its role in the modern states construction. But, the subject matter of national security in the system of public administrationhas not been clearly defined yet. In addition, at the level of national, regional and global relations the concept of national security is often associated with security strategies.

Review of the latest researches and literature. The problem of national security, systemic principles of its regulation and public administration in particular, has been investigated by many outstanding Ukrainian and foreign scientists V. Gorbulin, O. Vlasyuk, V. Gorovenko, O. Dzioban, B. Parakhonsky, G. Sytnyk, M. Trebin. Many scientists of the 
National Academy for Public Administration under the President of Ukraine (V. Abramov, S. Borysovych, A. Datsyuk, V. Mandragelya, R. Marutyan, Y. Melnyk and others) have already contributed to the investigation of national security problem.

Main objective of the article. In this paper the approaches for defining the «national security» concept in the system of public administration are analyzed. Moreover, it is necessary to determine socio-political subordination of these systems and clarify national security subjectivation and its regulation in the system of public administration.

Statement of the problem. The concept of «national security» has not been comprehensively defined yet. The category of security has an interdisciplinary importance. Hence, scientists define it in accordance with the subject matter and the specifics of cognition and research. But, security is regarded as an anthropocentric category which is related to man's social essence and value. Most scientists agree that security is a constituent of every aspect of human life. Thus, the consideration of security issues is of great importance.

Undoubtedly, there is a link between the social functions of development and security. It can be explained by the unity and interdependence of all spheres and types of human activity. Even the ancient Roman philosopher Cicero viewed these functions as fundamental ones in the state and society development: «... First of all, nature has granted all the species with the desire to defend themselves ... avoid everything that seems dangerous and get everything necessary for their life ...» [5, p. 234].

It is important to explain the lexical and etymological meaning of the word "security» which comes from the Latin word «securitas» that means «without any care, guardianship, or sufficient protection». Literally, security means a lack of threats (in English, danger) and a sense of confidence (in English, safety).

Most vocabulary definitions indicate that security refers to a state of confidence, calmness, lack of threat, and protection from danger. In «Academic Dictionary of Ukrainian language» issued in 11 volumes the word «security» is interpreted as a state when someone or something is not threatened» $[11, \mathrm{p} .386]$.

It should be noted that in psychology, «threat» means a specific psyche or consciousness state caused by unfavorable or dangerous phenomenon for a particular person, society, state, etc..The concept of security objectively correlates with the real threat, danger and their destructive consequences.

Security, in its literal sense, is interpreted as a need which may be primary, basic and the main. In the hierarchy of needs, known as Maslow's Pyramid, security takes one of the main positions, along with the fundamental physiological (existential) needs. Thus, security is understood, above all, as freedom from fear. According to Józef Kukulka, an outstanding Polish researcher, a lack of security needs satisfaction causes harm to individuals, social groups, as it destabilizes their existence and functioning [14, p. 29]. Consequently, the tendencies to change dangerous environment and to resist unfavorable changes gain prominence. It becomes inevitably important to use protective resources to restore the sense of security. Thus, it confirms that security is not only a certain state, but also a continuous social process in which the actors try to improve the mechanisms that provide them with a sense of security.

It is now generally accepted that the need for security is a motivation for action and development, owing to the fact that it is impossible to achieve social goals if the need for security is not realized. In general social meaning, the need for security refers to the desire for existence, survival, confidence, stability, independence, and protection of life standard and quality.

On the other hand, security is interpreted as a value, welfare, an exceptionally important belief in achieving goals. For instance, B. Brodier and M. Levy state that security is the main value that conglomerates other values. Many scientists consider security as a state (something realistic) or process (a changing phenomenon). Thus, Janusz Stefanowicz highliguts the 
security dual nature. He states that security is both the state and the process. However, it is not marked by consistency over long periods of time. On the contrary, it depends on forces dynamic distribution [14, p. 29]. Although, the prevailing opinion is that security first and foremost is the process. Particularly, Yu. Kukulka confirms that security is not so much a definite state as a continuous social process in which actors try to improve the mechanisms ensuring a sense of security. Therefore, security is not marked by constancy and depends on changing dynamics at different levels of social life [14].

It should be noted that there are other scientific approaches to define security as a goal, consequence or resource. Though, to some extent it often narrows the phenomenon of security considering it to be the phenomenon peculiar to the period of wars or other social upheavals. As a result, such limited approach, based solely on military aspects, does not contribute to an accurate and critical analysis of security subjective side.

The expansion of spatial dimension complements the subjective definition of security. According to this criterion, it is possible to distinguish local, subregional, national and global levels of security, which correlate with state and national security level. Thus, despite continuous social and political changes, the state and the nation remain the key categories where security system is directly related with.

Recently, there has been wide interest in the approach that linked security with the state and its development. Hence, at the beginning of the XXI century the subjective side of security began to be correlated with the nation.

From social sciences perspective, state security and national security are either identical or interchangeable concepts. However, some researchers emphasize a significant distinction between these two concepts pointing to differences in the definition of nation and state, despite the theories that define the state as a system in which the nation acquires a substantive status. Although in the culturalist theories of the nation, the state is interpreted as a secondary element in relation to the nation.

Many foreign scholars, Buzan, Viviera, and Vildea in particular, clearly distinguish between the concepts of state and national security. Correspondingly, they consider it unacceptable to identify or replace these categories. Moreover, they prove that the concept of nation is much narrower, although the concept of state stems from it.

After all, national interests development and protection of interpersonal, group, intergroup, interclass levels is the basis and condition forstate organization formation and functioning. Therefore, national security is a part of state security as the supreme institution in the society organization.

However, according to some theories, the citizenry is primarily a community united by culture (tradition, language or religion), which can function without the state. Therefore, in English, both terms «national security» and «state security» mean the security of the state as a whole. Although, this concept has a deeper meaning, as it equally implies the territory and the people who live on it. In social sciences, state security is understood primarily as a system of values, which include survival (of the people and the state), political (system, sovereignty) independence, quality of life (at the social, economic and cultural levels).

However, security presupposes much more values such as the state prestige or citizens affairs outside the country. Thus, national security as a category is narrower in its meaning in comparison to the state security. It is related to values protection that guarantees people survival especially in the period of statehood loss or outside the country territory. Therefore, national security is believed to protect the internal values of the state, for instance, those that are existential in nature. Consequently ,national security is viewed as a kind of state security. Moreover, due to globalization national security is gaining new features, as it goes beyond the interests of the state, though it does not become a part of international security. 
Statement of main problems of the investigation. The category «national security» originated as a foreign policy and is an entirely American invention. At the country level it was used for the first time in 1904. Theodore Roosevelt, the former US President, used this term in his message to the US Congress to justify the accession of the Panama Canal in the interests of national security $[8$, p. 17]. Since then, national security has been the subject of investigations in the field of political science. Then the term was used in normative legal acts and became the subject matter of legal and social sciences. Additionally, strategic research can be considered as an area of national security problems development. It presupposes a thorough analysis of foreign and domestic policy situation, taking into account a wide range of objective and subjective factors carried out by special institutions commissioned by central government. The results of it are of great importance for making political decisions [8, p. 21].

American tradition to define the concept of national security is based on the theory of national interests. It presents the model of the relationship in which national security is considered as a part of national interests. This model is widely recognized at present. It was first introduced by American W. Lippman. This issue was also of great interest for many other outstanding scientists such as B. Brody. M. Halperin, G. Kahn. G. Kissinger, G. Laswell, G. Morgenthau [8, p. 53].

The introduction of the categories «national security» and «national interests» into political and legal circulation resulted in their negative use. Firstly, these concepts referred to illegal and anti-democratic actions. That is, we mean certain inconsistencies in the law-making and law-enforcement aspects of these categories. They have become a convenient tool for international and domestic policy. Their use in the international sphere has its peculiarities. At the beginning of the XX century international law developed into a system that significantly limited the actions of the state. Therefore, it was necessary to find a justification for the restrictions violation. The justification of international law norms negligence by the need to protect national security proved to be quite effective. Unfortunately, the same happened to the category of national security in domestic sphere. In the USA it was also used as an excuse to restrict civil liberties, for instance, the Communist Control Act of 1950, according to which any organization recognized as communist was immediately declared illegal and lost all the rights.

In the USSR such terminology was not used.It appeared only in 1990 with the creation of the National and International Security Fund. This can be probably explained by the fact that the USSR had its own way to justify their illegal actions [2, p. 138].

The process of the state interests and security defence is directly related to the state policy implementation, within which specific measures are taken in order to implement them. Moreover, there is an opinion that national security is the state policy aimed at creating appropriate domestic and international conditions to preserve or strengthen national values. It protects the interests of the people, the state, the society and its members [3, p. 22].

However, in any interpretation, the terms «security» and «danger» are related to the conditions of a particular object functioning, which is characterized, respectively, by a real or potential threat absence or presence. The state policy is a certain system of appropriate measures, a special management system. It acts as a tool that changes or tries to change the conditions of object functioning, reducing or increasing the threat.

In general, the national security policy in the system of public administration is aimed at reducing and avoiding existing and possible threats to normal state development in accordance with its goals. In addition, it is a part of the national interests of the country.

Considering security and defence transformation threats, which are real challenges in the development of modern Ukraine, it is extremely important to define specifically Ukrainian national security and its direction.

There are several definitions of national security. However, none of them is comprehensive enough. In the encyclopedic edition, national security is understood as the 
country's ability to preserve sovereignty, political, economic, social and other foundations of public life and to act as an independent subject of international relations [10, p. 489]. National security refers to the defence of the interests of the individual, state, society, state borders, territorial integrity, socio-political system, cultural values etc. It implies the defence of everything that corresponds to material and spiritual life of the country against internal and external threats $[11$, p. 386].

From the legislative perspective, the definition of national security is too over loaded with details. However, it emphasizes the ability of state-building forces to outline national security issues. Therefore, national security is viewed as the defence of vital interests of the man and the citizen, the society and the state. It ensures sustainable development, well-timed detection, prevention and neutralization of real and potential threats to national interests in such areas as law enforcement, anti-corruption, border activities and defence, migration policy, health care, child protection, education and science, scientific and technical policy, innovation policy, cultural development of the society. It contributes to the speech freedom and information security, social policy and pensions, housing and communal services, financial services market, property rights protection, and securities markets. It facilitates fiscal and customs policy, trade and business, banking services, investment policy, auditing, monetary and exchange rate policy, information protection, licensing, industry and agriculture, transport and communications, information technologies, energy and energy conservation. It administers the functioning of natural monopolies, the use of subsoil, land and water resources, minerals, protection of ecology and the environment and other areas of public administration. Thus, it protects from potential or real threats to national interests [6, p. 563].

The Law of Ukraine on National Security of 2018 states that national security of Ukraine implies the defence of state sovereignty, territorial integrity, democratic constitutional order and other national interests of Ukraine against real and potential threats [6, p. 564]. Therefore, the key function in national security regulation is entrusted to the system of public administration, which is a particularly important area of activity and law and order establishment.

Public administration is a type of a state activity, the implementation of managerial organizational influence. It is done by means of executive power of the organization of law enforcement, management functions for state integrated socio-economic and cultural development, its individual territories, implementation of state policy in the areas of public life, creating conditions for citizens to exercise their rights and freedoms [1, p. 32].

Conclusions. In conclusion, national security management is a system of extensive causal links between the nation and the need to achieve the security state in today's globalized world, which constantly generates various types of challenges, threats and dangers. This system, based on national interests and values, is more complex entity than the system of national security. Thus, the formation of the state management by national security on the basis of treaty and legal regulation is a priority for the development of their own statehood and security for all civilized nations of the world. Therefore, the introduction of effective mechanisms of public administration in the field of national security is a strategic priority for the implementation of domestic and foreign policies of the leading states of the modern world in the process of globalization.

\section{References}

1. Vysotsky O. Y., Vysotskaya E. E., Sharov Y. P. Fundamentals of public administration. Part I. Dnepropetrovsk: NMetAU, 2008. 52 p.

2. Vlasyuk O.S. National security of Ukraine: the evolution of problems of domestic policy: selected. Science. Kyiv Avenue: NISD, 2016. 527 p.

3. Vonsovych O.S. National security of Ukraine in terms of modern geopolitical changes. Scientific Bulletin of the Diplomatic Academy of Ukraine. 2017. Vol. 24 (2). P. 18-24. https://doi.org/10.25140/2410-9576-2017-2-2(10)-24-30 
4. Global and national security: a textbook [V. I. Abramov and others], for general ed. G. P. Sitnik. Nat. acad. state упр. under the President of Ukraine, Communities. org. "Acad. nat. Security". Kyiv: NAPA, 2016. $781 \mathrm{p}$.

5. Kuras A. I. National Security of Ukraine: military-political paradigms. Scientific notes [Institute of Political and Ethnonational Studies. IF Kuras]. 2014. Vol. 2. P. 230-240.

6. Surmin Y. P. System. Encyclopedia of public administration: in 8 volumes. Nat. acad. state yпр. under the President of Ukraine; scientific editor board: Yu. V. Kovbasyuk (chairman) and others. Kyiv: NAPA, 2011. Vol. 2: Methodology of public administration / scientific-ed. Board: Yu. P. Surmin (co-chairman), P. I. Nadolishniy (co-chairman) and others, 2011. P. 561-565.

7. Public administration in the field of national security: a dictionary-reference, ed. G. P. Sytnik. Kyiv: NAGU under the President of Ukraine, 2012. 496 p.

8. Chernyshova T. O. Nation. Political science encyclopedic dictionary / compiled by: [L. M. Gerasin, V. L. Pogribna, I. O. Polishchuk and others], for order. M. P. Trebin. Kharkiv: Pravo, 2015. P. 467-468.

9. Global and national security, ed. count V. I. Abramov, G. P. Sitnik, V. F. Smolyanyuk, for general ed. G. P. Sitnik. Kyiv: NAPA under the President of Ukraine, 2016. 784 p.

10. Kornievsky O. National security. Political Encyclopedia, editor: Yu. Levenets (chairman), Yu. Shapoval (deputy chairman) and others. Kyiv: Parliamentary Publishing House, 2011. P. 489-490.

11. Tupchienko L. National security. Political Science Encyclopedic Dictionary, ed. Yu. S. Shemshuchenko, V. D. Babkin, V. P. Gorbatenko. Kyiv: Genesis, 2004. P. 386-387.

12. On national security of Ukraine: draft law of Ukraine dated February 28, 2018. URL: http://w1.c1. rada.gov.ua/pls/zweb2/webproc4_1?pf3511=63531.

13. Dictionary of the Ukrainian language in 11 volumes. URL: https://slovnyk.ua/.

14. Kukulka J. Security and European cooperation: interdependencies and conflicts of interest. "International affairs", 1982, issue 7, p. 29.

\section{Список використаної літератури}

1. Висоцький О. Ю., Висоцька О. С., Шаров Ю. П. Основи державного управління. Частина I. Дніпропетровськ: НМетАУ, 2008. 52 с.

2. Власюк О. С. Національна безпека України: еволюція проблем внутрішньої політики: вибр. наук. пр. Київ: НІСД, 2016. 527 с.

3. Вонсович О.С. Національна безпека України в умовах сучасних геополітичних змін. Науковий вісник Дипломатичної академії України. 2017. Вип. 24 (2). С. 18-24. https://doi.org/10.25140/2410-9576-2017-2-2(10)-24-30

4. В. І. Абрамов та ін. Глобальна та національна безпека: підручник / за заг. ред. Г. П. Ситника. Київ: НАДУ, 2016. $781 \mathrm{c.}$

5. Курас А. І. Національна безпека України: військово-політичні парадигми. Наукові записки. 2014. Вип. 2. С. 230-240.

6. Сурмін Ю. П. Система. Енциклопедія державного управління: у 8 т. / Нац. акад. держ. упр. при Президентові України; наук.-ред. колегія: Ю. В. Ковбасюк (голова) та ін. Київ: НАДУ, 2011. Т. 2: Методологія державного управління / наук.-ред. колегія: Ю. П. Сурмін (співголова), П. І. Надолішній (співголова) та ін. 2011. С. 561-565.

7. Государственное управление в сфере национальной безопасности: словарь-справочник/ под ред. Г. П. Сытника. Киев: НАГУ при Президенте Украины, 2012. 496 с.

8. Чернишова Т. О. Нація. Політологічний енциклопедичний словник / уклад.: Л. М. Герасіна, В. Л. Погрібна, І. О. Поліщук та ін. / за ред. М. П. Требіна. Харків: Право, 2015. С. 467-468.

9. Глобальна та національна безпека / авт. кол. В. І. Абрамов, Г. П. Ситник, В. Ф. Смолянюк / за заг. ред. Г. П. Ситника. Київ: НАДУ при Президентові України, 2016. 784 с.

10. Корнієвський О. Національна безпека. Політична енциклопедія / редкол.: Ю. Левенець (голова), Ю. Шаповал (заст. голови) та ін. Київ: Парламентське видавництво, 2011. С. 489-490.

11. Тупчієнко Л. Національна безпека. Політологічний енциклопедичний словник / за ред. Ю. С. Шемшученка, В. Д. Бабкіна, В. П. Горбатенка. Київ: Генеза, 2004. С. 386-387.

12. Про національну безпеку України: проект закону України від 28.02.2018. URL: http://w1.c1. rada.gov.ua/pls/zweb2/webproc4_1?pf3511=63531.

13. Словник української мови в 11 томах. URL: https://slovnyk.ua/.

14. Kukułka J. Bezpieczeństwo a współpraca europejska: współzależności i sprzeczności interesów. «Sprawy międzynarodowe», 1982, issue 7, p. 29. 